\title{
ポリビニルアルコール繊維の延伸率と収縮挙動について
}

\section{瀻維工業訊験所 古矢宏 \\ ON THE DRAW RATIO AND THE SHRINKING BEHAVIOUR OF POLYVINYL ALCOHOL FIBERS}

By Hiroshi Furuya

(The Textile Research Institute of Japanese Govermment, Yokohama, Japan.)

Isotropic polvinyl alcohol filaments were stretched to various degrees in different media.

For the stretched flaments, the tensile strength and elongation were measured in both wet and dry states.

Shrinkage was also observed in gradually heated water.

The changes of filament length at the softening point and at the solubility point were calculated from the standard length.

This has led to the conclusion that the softening point can be characterized as the point at which Young's modulus becomes very low.

Since the filament length at solubility point corresponds to the length at the effective draw, some frame-work structure must be considered in the inner part of the flament.

The shape of shrinkage curves can be interpreted qualitatively considering the distribution of secondary bond strength.

(Received. 17. 12. 1956)

\section{1. 緒言}

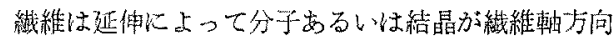
に配列する。この結果伸度惊減少し强度は上算する。 ここで延伸の效果壱絸察するにあたっては，瀻維の前 歴を明らかにしておくことが重要である。たとえに゙切

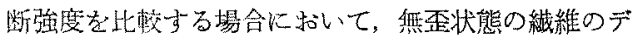
ニールむたり切断荷重すな放ち通管の切断強度で表示

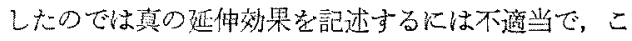
の場合はむしる强力方るいは可断時デニールあたりの 荷重であらわすのが此烄のた放には便利である。

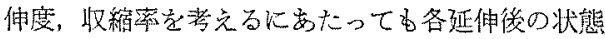

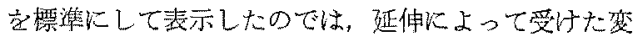

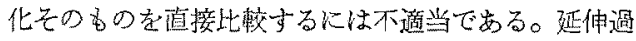

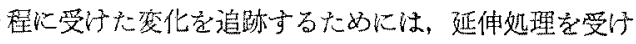

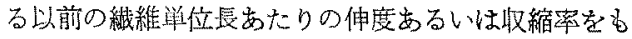

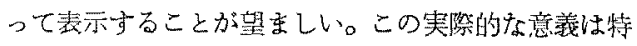

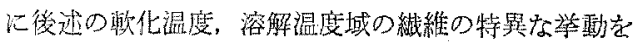
考完る時比らがなる。

\section{2. 実験}

（A）延伸方式と有効延伸率
原織維はでさるたけ緊張のかからない状態で紀糸し たもの学瀿国浴程類のついたまま風乾し更に $100^{\circ} \mathrm{C}$ 礐時间加熱乾燥した。

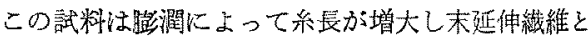
して用いるもの適しているい。先に述べたような表 示定するためには，種々の延伸操作によって增加した 䋘稚長が延伸前に比較してどの程度の偣率に延伸され

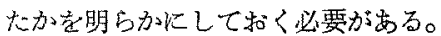

このために延伸浴ならび延伸率学にする条件下

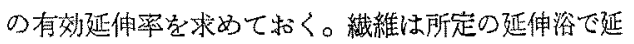
伸後无の变ま10分間置きそれから負荷觉取除く。延伸 率とは延件機で実際にあだたた延伸倍数である。この

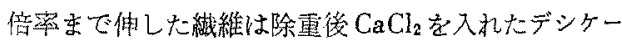

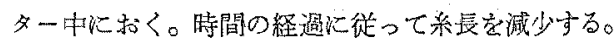
系長が安定した時の倍率を有効延伸率として表示した。 延伸浴条件；
A : 流動パラフィン浴
$80^{\circ} \mathrm{C}$
B : $"$ t
$120^{\circ} \mathrm{C}$
C: $\mathrm{Na}_{2} \mathrm{SO}_{4}, \mathrm{ZnSO}_{4}$ 混合水溶液 $80^{\circ} \mathrm{C}$

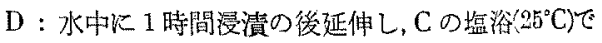
固定
$\mathrm{E}: " \|$
"l
$\left(80^{\circ} \mathrm{C}\right) \prime \prime$ 
な叔熱処理フォルマール化はおのおのの有效延伸寗 に対応寸る系罳に固定して行った。

それぞれの延伸浴についての延伸率と有效延伸率の

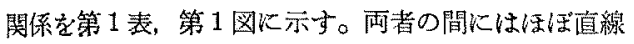
関係加成立与号。

Table 1 Effective draw ratio in various medium

\begin{tabular}{|c|c|c|c|c|c|}
\hline draw ratio & 2 & 3 & 4 & 5 & 6 \\
\hline sample & & & & & \\
\hline A & 1.63 & - & 3.13 & - & 4.75 \\
B & 1.83 & 2.50 & 3.60 & - & 5.35 \\
C & - & 2.66 & 3.45 & 4.35 & 5.20 \\
D & 1.62 & 2.50 & 3.33 & 3.95 & 4.80 \\
E & 1.86 & 2.86 & 3.80 & 4.65 & 5.50 \\
\hline
\end{tabular}

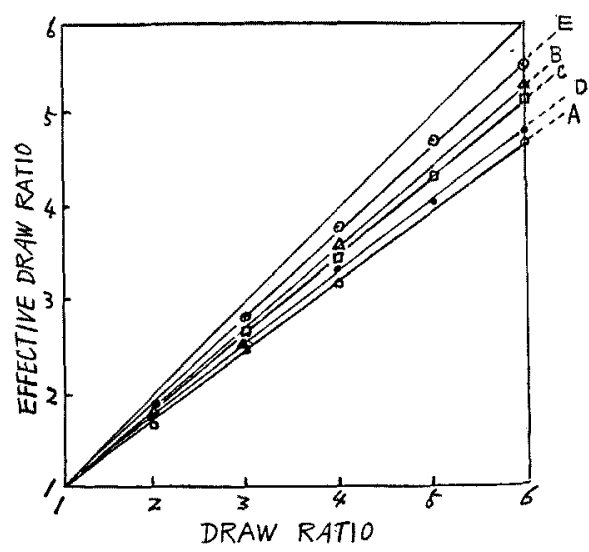

Fig. 1

(B) 膨閏延伸による力学的性罂の变化

延伸処理の効果を钼察する最も簡紧を目安として膨 淍延伸試料 DKついて乾湿两状態に战子る切断㤝伸度 の測定を試みた。(第2 図)

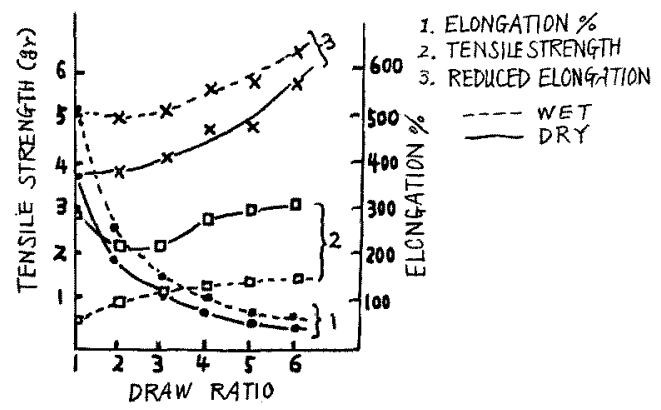

Fig. 2 Effect of stretch on tensile strength and elongation.

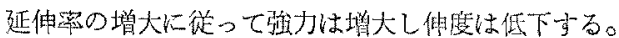
今伸度定延伸前の単位蟣維長に対与る伸度(仮りに換

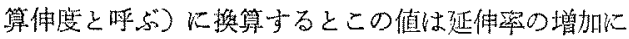
従って增大する。すなわち膨潤延伸によって内部啃造 にかなりの変化が起っていることが容易に想像され， 水中での膨潤延伸によっても結鼠化ないしは新らしい 結合が生成していると考えられる(ただし延伸率1す なわら末延伸瀻維は膨潤処理を受けていない。

(C) 水中収縮率の測定

測定は第 3 図の如く二重壁にした硝子管中に䋐維を

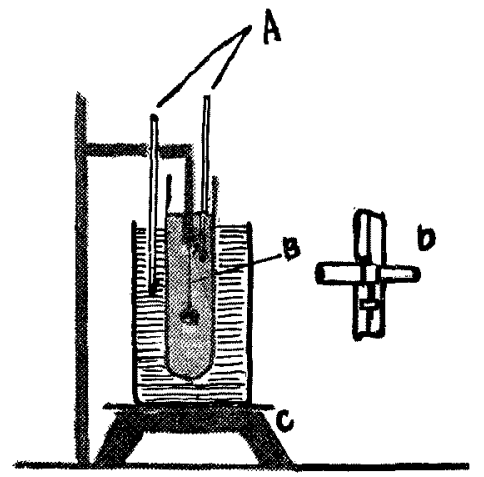

Fig. 3 Apparatus for shrinkage measurment.
A, thermometer
B, sample
C, heater
D, cathetometer

保持し，他端に細い、銅線を吊し㵶維を重直に保つ。負 荷は単繊維当り $1.5 \mathrm{mg}$ である。水浴の温度上年濑度は $2{ }^{\circ} \mathrm{C} / \mathrm{min}$ 程度に調節した。測定中磨々試北あるいは真 荷としてて使用子方銅線表面に気泡が付着し測定に不正 碓を来すのでこの点特に注意する必要が岕った。

混度上升に优。て始め㵶維は収綟を起しある温度域 を過ぎると伸長を開始する(この牟移温度学水中軟化 点と呼ぶこれらのうち未熱処理瀻維についての测定

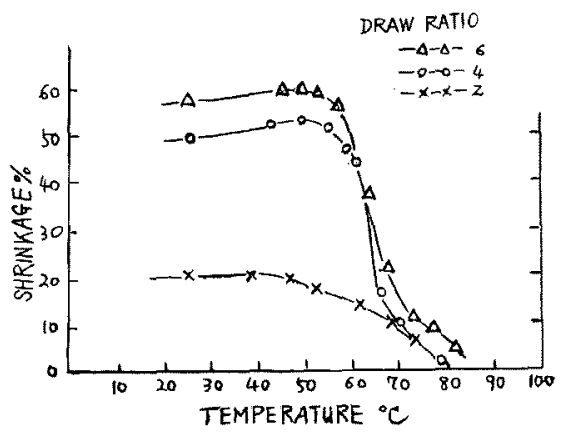

Fig. 4 Stretching bath A 


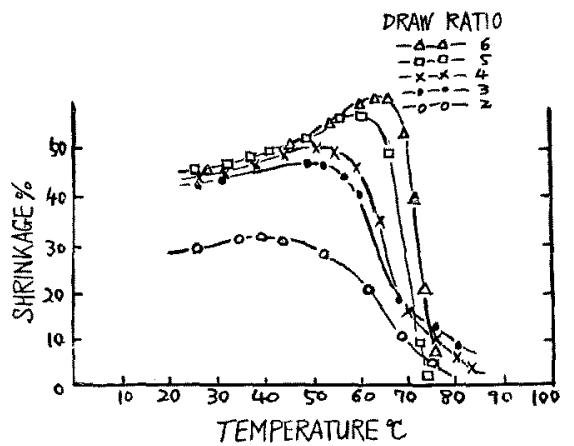

Fig. 5 Stretching bath D

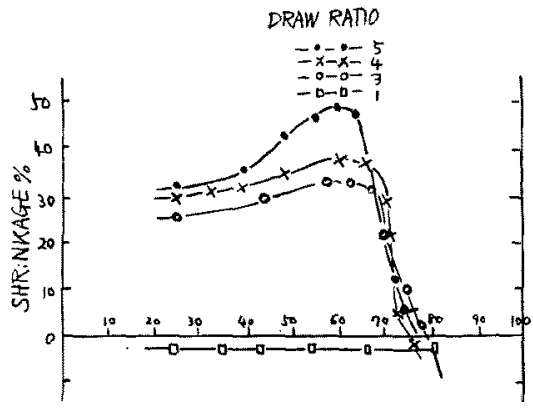

Fig. 6(a) Stretching bath $\mathrm{C}$

結舆を第 4.5.6. 図に示す。ただし第6图（b）のAは C 浴で延伸後系艮を国定し常温の水中で膨潤処理した 場合，B结固定惊ず処理したるのである。収縮密\%は 水浸前の乾蜗時にお湖る糸長に対寸る水中の系長の百

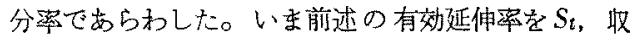

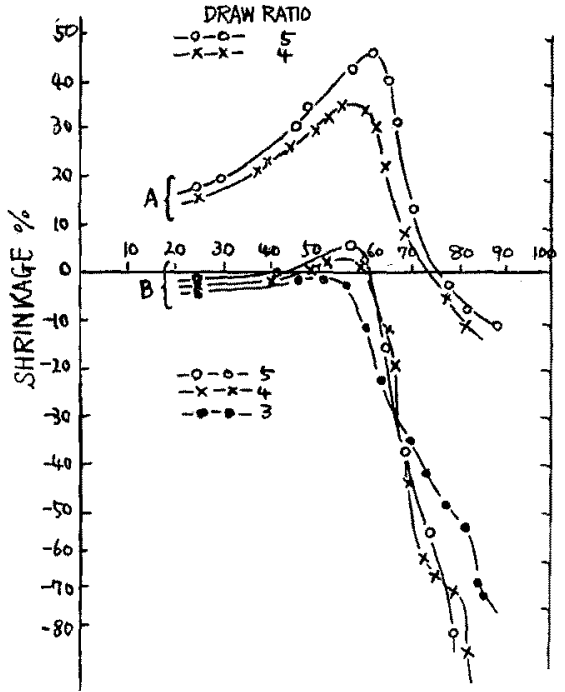

Fig. 6 (b) After swelling treatment
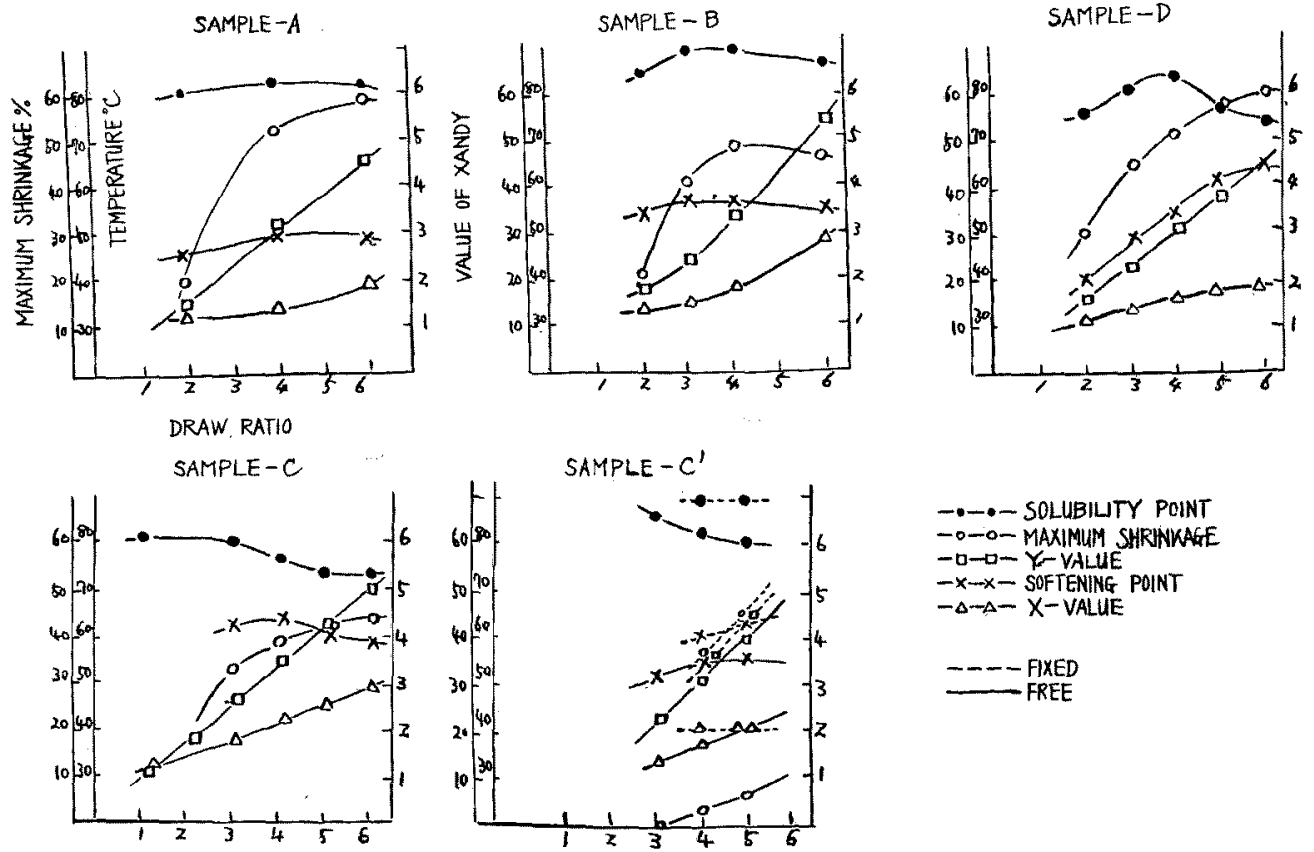

--- SOLUBILTYY POINT

-O-O- MAXIMUM SHRHNAGE

$-\square \rightarrow \square-Y-V A L U E$

$-x-x-$ SOFTENING POINT

$-\Delta \rightarrow-X-$ VALUE

--- FIXED

Fig. 7 Shrinkage elongation character 


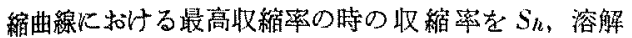
切断封の収綟密を $\left[S_{h}\right] c$ とすると，延伸前の原采長 に対する最高収繀時伸長倍数 $X$, お。び包断時の総伸 長倍数 $Y$ はそれぞれ次式で与えられる。

$$
\begin{aligned}
& X=S_{t}\left(1-S_{l} \times 10^{-2}\right) \\
& Y=S_{t}\left(1-\left[S_{h}\right]_{t} \times 10^{-2}\right)
\end{aligned}
$$

これらの計算結果を第 7 図に総括した。第7図C は 第6 図 (b) と同一試料洞関する測定結果を示したもの で他の場合と同栐に $X$ および $Y$ は末処理瀻維を標準 㳊算出した值である。最高収縮寀は水で膨潤処理した 後の風彰系長を基準に計算した值である。

次に熱処理，フォルマール化した試料について前 と同様な方法で収縮率を测定した。整処理は $180^{\circ} \mathrm{C}$, $220^{\circ} \mathrm{C}$ の各温度で行った。一例を第 8 図, 第 9 図に示 した。熱処理によって收縮率曲線の形は著るしい変化 を受ける。更にこれをフォルマール化すれば，その樣 子は全く変化し $180^{\circ} \mathrm{C}$ 熱処理試料をフォルマール化す れば䡆化温度はすらわれない。

\section{3. 実験結果の考察}

\section{3-a 延伸率と有効延伸率}

延伸条件として5種の媒体中で1ないし6 倍の範团

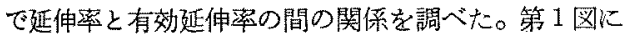
見られるように総ての場合，延伸率と有効延伸率の間 に活浯直線関保が成立する。乾熱延伸に比して湿熱延 伸の方が永久变形は大であり，特に水中延伸の場合は こ机方顕著である。永久夜形の一部分は杀状分子の配 向以外飞，延伸時に起る結合の部分崩壊，マクロ流動 など基つくくのと考它られる。実際に第 7 图の $X$ 值

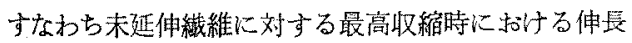
率を見ると，これらの值も延伸率ととも增大する傾 向を示している。この測定が温水中でから微小荷重下 で行われていることを考觉ると， $S_{h}$ の値は真の意味

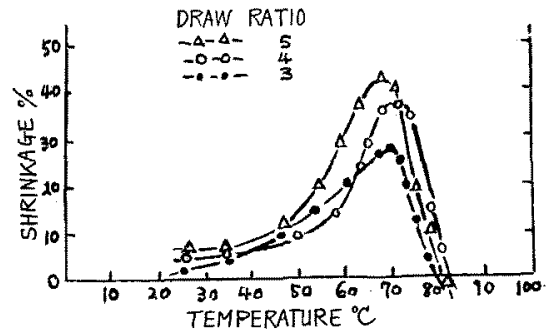

Fig. 8 Shrinkage curve of thermotreated filament $\left(180^{\circ} \mathrm{C}\right.$ treated) stretching bath $\mathrm{C}$

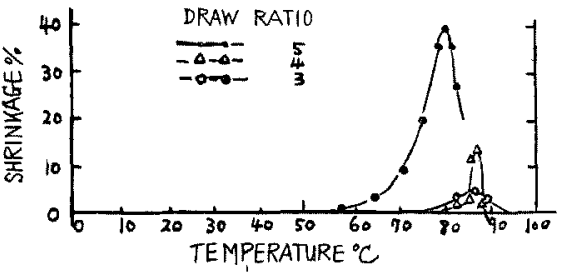

Fig. 9 Shrinkage curve of thermotreated filament $220^{\circ} \mathrm{C}$ treated stretching bath $\mathrm{C}$

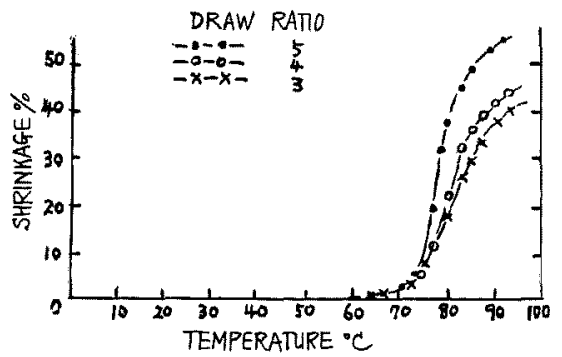

Fig. 10 Shrinkage curve of formarized filament thermotreated at $180^{\circ} \mathrm{C}$

の最高収縮率と見なされる。Xの值の大小は延伸時の マクロ流動の尺度となし得る。

\section{3-b 水中軟化点}

フォルマール化した䋐維以外は総て収縮菜䌷線に極 大值が表われる。

瀻維が水中で膨潤し分子部分の運動性が活潑となる と形態因子によって系状分子は屈曲し瀻維は收綟する。 温度上㫒促って次第に結合の綏和が起り, この傾向 は顕著となるが，ある温度域に到達するといますでと は逆に瀻維長が增大する。この転移温度が水中軟化点 である。収縮曲線を見ると明らかな上ろに，この温度 域に拁ける杀長は乾燥時の采長上り著るしく小さく， 伸長を始好るためには未だ巨大分子周相互の迄りを必 要としない。をた第 7 図の $Y$ 值とその時の $S_{t}$ を参照 すると両者は添隹等しい。すなわち溶解切断時に括け る伸長度に相当する系長性有効延伸率儿相当す白系長 に等しいことが放かる。更にまた末延伸織維では軟化 点はあら和れない。これらの事寒を侾虑仅入机ると靯 化温度に执いてはマクロ流動よりはむしろ結び目の結 合緩和による弾性率の急激な低下が起り，微小荷重に よって伸長が開始するるのと考克られる。

\section{3-c 軟化温度之溶解温度}

溶解切䉼する温度付近の収樎伸長变化を観察すると， 未熱処理䄉維に批いては水中軟化点を経てから伸長を 
開始しり断点付近で伸びが一時得止し透明化して溶解

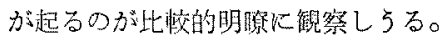

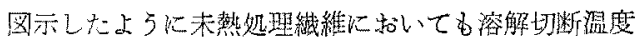
はかなり高い。しかしながら瀻維束をこの温度まで徐

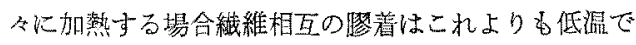
起る。すなわち一般に噖着温度は溶解切断の温度より 毛や户低

\begin{tabular}{|c|c|c|c|}
\hline 処 理 桑 件 & 欶化, & 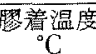 & $\begin{array}{c}\text { 容解温度 } \\
{ }^{\circ} \mathrm{C}\end{array}$ \\
\hline 原瀻維 & - & 63 & 82 \\
\hline $80^{\circ} \mathrm{C}$ ハラフィン浴 2 倍延伸 & 46 & $55 \sim 60$ & 81 \\
\hline $80^{\circ}$ ヘラ゙フイン浚 3 借延俩 & 50 & $55 \sim 60$ & 83 \\
\hline 水中延伸塩溶源浴 $\left(25^{\circ} \mathrm{C}\right)$ & 64 & $64 \sim 66$ & 82 \\
\hline 䭪数溶硕 $\left(80^{\circ} \mathrm{C}\right) 4$ 倍题伸 & 63 & $63 \sim 66$ & 76 \\
\hline
\end{tabular}

一部の試畨について行った結果を上に示したが，こ

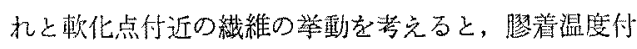
近て践維は等奏上，部分的な浴解を始めていると思わ

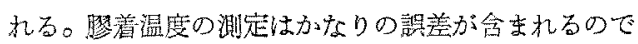
政密な值は不明であるが軟化点とは明らが区区别され る。膠着温度と溶解温度の間では变化は急激でるる。

\section{3-d 収縮裹曲線の温度勾配}

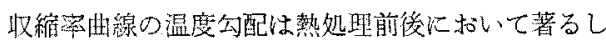

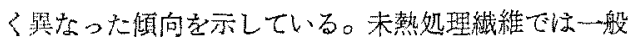
に常温の水中に浸皘した時に大部分の收縮が起ってし ま5のに齐して熱処理した䄉維ではかなり高温域で初 めて収縮が認められる。収縮の可否は延伸後における 秝状分子相互の綕合の安定性に依存するるので，分子 相互の結合が緩和されれば楼接領城の分子部分が蕉運 動頜域を扰大寸ることによって取縮が起る。媒体湜度 の上年によって次第に強い結合の緩和が起り従って収 樎率的增大寸る。従って収樎率の温度変化は分子間に 作用する結合の强度分布に関係を持つ。热処理紻維で
は収縮は高温で急激に运り比較的強い結合が主要部分 を与めているのに刘して，未熱処理維維では常湿て緩 和されるような弱い結合が支配的でかる。延伸浴の秼 件によって子結合分布はかなり相異している。もちろ ん如何なる結合の緩和す同しで収縮率をすたらすので はないから定性的な目安となるに過ぎない。実際に緸 維の種々の力学的性能を特徽づけるのは傿定形部分の 結合分布ですり，膨潤性，吸着能るまたこれが主要な 因子となる。

\section{3-e 延伸後の膨潤処理による变化}

策6 图ならびに第 7 图 C'を見るとかなり 特街ある 变化が虫められる。すず自由な状態で膨潤処理したる のに対して，固定処理したものは軟化温度，溶解温度 とすに高くまた収縮率の温度公配は著るしく大きくな っている。最高取縮率を比較すると第6 図のA試料 は未膨潤処理試料上大美ないが常湿付近の収縮率は明 らかな相異示す。

以上の事実にかかわらず $Y$ の值は第 6 図の後処理 条件の異なる 3 試料の間でほとんど盖罢がない。これ は溶解切断時の系長が有効延伸率とかなり密接な関绿 を持っていることを意味する。すなるら延伸処理の際 に受けた履歴がこの系長になんらかの骨格組織を与文 ていると解䐆できる。これらの事実るまた軟化温度に 指子るマク口流動の可能性を否定する。上記の溶解可

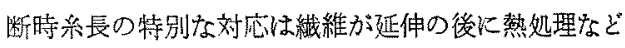
る受けていない場合に成立つものであり，熱処理，ま るいはフォルマール化処理を行っだ埸合には別の举動 索示す

\section{文献}

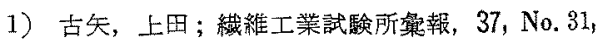
(1954)

\section{昭和 31 年秋期研究発表会要旨頒布について}

昨年10月27日，28日名古屋に和いて開催した本学会路独の研究発表会の䍊旨が残って和りますから希望者

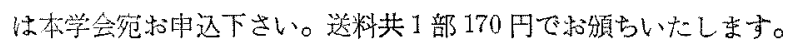

